\title{
PENGUKURAN KEPUASAN PENGGUNA DAN PENINGKATAN LAYANAN AKADEMIK ONLINE DI UNIVERSITAS MAJALENGKA
}

\author{
Dede Abdurahman ${ }^{1)}$, II Sopiandi ${ }^{2)}$ \\ Program Studi Teknik Informatika, Fakultas Teknik, Universitas Majalengka ${ }^{1)}$ \\ Email :dzildan@gmail.com \\ Program StudiTeknik Informatika, Fakultas Teknik, Universitas Majalengka ${ }^{2}$ \\ E-mail: supiandi999@gmail.com
}

\begin{abstract}
The development of Information and Communication Technology penetrated to various aspects, not only in the field of business oriented, but also in the areas of government and education. Similar to other fields, in the field of education, Information and Communication Technology is one of the main needs for quality education. This study is an analytical survey to measure the level of satisfaction of SIMAK or web-based online application. Methods of data collection by spreading questionnaires to respondents or students as users of academic services at Majalengka University. The research models and instruments are based on the Customer Information Satisfaction (CIS) model, where after selection and testing the five dimensions of measurement are customer service, security, ease of use, information content, and innovation. Furthermore, based on these 5 dimensions composed an instrument or attribute measurement consisting of 15 questions.
\end{abstract}

Keywords: SIMAK, WEB, Customer Information Satisfaction (CIS)

\section{PENDAHULUAN}

\subsection{Latar Belakang}

Aplikasi berbasis web merupakan salah satu aplikasi yang berjalan di atas browser, dan sangat relevan untuk membantu kebutuhan sebuah informasi. Layanan Akademik yang berbasis web juga dapat digunakan untuk memberikan kemudahan kepada mahasiswa dalam rangka mendukung dan mempercepat proses perkuliahan. Hal ini terkait dengan implementasi sistem akademik di Universitas Majalengka yang sudah dilakukan sejak tahun 2014, dan terkait loyalitas sistem akademik maka diadakan sebuah evaluasi terhadap pengguna sistem akademik berbasis web dengan pengelola sistem akademik tersebut, dalam rangka peningkatan kwalitas pelayanan terhadap mahasiswa dan dalam rangka menyelaraskan dengan visi misi Universitas Majalengka 2020. Model kepuasan pengguna (user satisfaction) difokuskan untuk meninjau sejauh mana usabilitas mahasiswa menikmati layanan akademik, penelitian ini dilakukan untuk mengukur tingkat kepuasan pengguna web pada sistem akademik Universitas Majalengka.

Model dan instrumen penelitian didasarkan pada model Customer Information Satisfaction (CIS), di mana setelah dilakukan pemilihan dan pengujian diperoleh 5 dimensi pengukuran yaitu customer service, security, ease of use, information content, dan innovation. Selanjutnya, berdasarkan 5 dimensi ini disusun instrumen pengukuran yang terdiri dari 14 butir ditambah satu butir yang mengukur kepuasan pengguna secara keseluruhan.
Penelitian ini merupakan penelitian survey analitik untuk mengukur tingkat kepuasan simak atau aplikasi online. Metode pengumpulan data dengan cara menyebar angket terhadap mahasiswa sebagai pengguna layanan akademik. Model dan instrumen penelitian didasarkan pada model Customer Information Satisfaction (CIS), di mana setelah dilakukan pemilihan dan pengujian diperoleh 5 dimensi pengukuran yaitu customer service, security, ease of use, information content, dan innovation. Selanjutnya, berdasarkan 5 dimensi ini disusun instrumen pengukuran yang terdiri dari 15 butir.

\subsection{Landasan Teori}

Agarwal \& Venkatesh (2002) menyatakan konsep pengukuran usabilitas menurut Microsoft Usability Guideline. Dalam penelitiannya, mereka melakukan penyusunan kategori dan sub kategori usabilitas berdasarkan pembobotan (weights) dan pemberian peringkat (rating). Cooper dan Schindler (2013) mengungkapkan bahwa penelitian yang mendasarkan pada teori atau hipotesis yang akan dipergunakan untuk menguji suatu fenomena yang terjadi digolongkan pada jenis penelitian eksplanatori (penjelasan). Penelitian eksplanatori melakukan studi terhadap hubungan antara dua atau lebih variabel, kemudian berusaha untuk menjelaskan fenomena yang terjadi. Menurut Yaghoubi, et al., 2011, Information Quality mengacu pada kualitas konten website dan relevansi informasi terhadap tujuan pengguna, misalnya, tingkat akurasi, konteks, format/bentuk, dan 
relevansi informasi. Turban and Gehrke (2000) juga menekankan bahwa kualitas informasi website menentukan apakah konsumen akan tertarik atau melayang jauh dari sebuah website (Kabadayi \& Gupta, 2011).

Mardiana, Ardi. Dengan judul Tingkat Kepuasan Mahasiswa Terhadap Kinerja Sistem Informasi Akademik dan Keuangan (Studi Kasus: Universitas Majalengka). Infotech Journal, 2016, 1.2. Penelitian melibatkan enam variabel diantaranya Kualitas Sistem, Kualitas Informasi, Kemudahan Penggunaan, Kepuasan Pengguna, Fleksibilitas dan Penggunaan Sistem. Total responden yang harus dihitung adalah sebanyak 378 orang. Hasil tersebut didapatkan dari hasil penentuan jumlah sample menggunakan rumus Slovin. Kuisioner diisi oleh mahasiswa ketika mereka mengakses SIMAK. Setelah dilakukan uji validitas dan uji reliabilitas instrumen menggunakan SPSS 20, didapatkan dari 34 indikator hanya 29 pertanyaan valid untuk disebarkan kepada responden .Alat hitung yang digunakan untuk mengolah data dari hasil kuisioner adalah AMOS 21. Bedasarkan hasil uji kesesuaian model, disimpulkan bahwa model yang diajukan sudah cukup untuk bisa kemudian dilanjutkan pada pengujian hipotesis. Dari 8 (delapan) hipotesis yang diajukan, hanya 6 (enam) hipotesis yang dibisa diterima.

\section{METODOLOGI PENELITIAN}

Metodologi penelitian tertuang dalam gambar 1 di bawah ini :

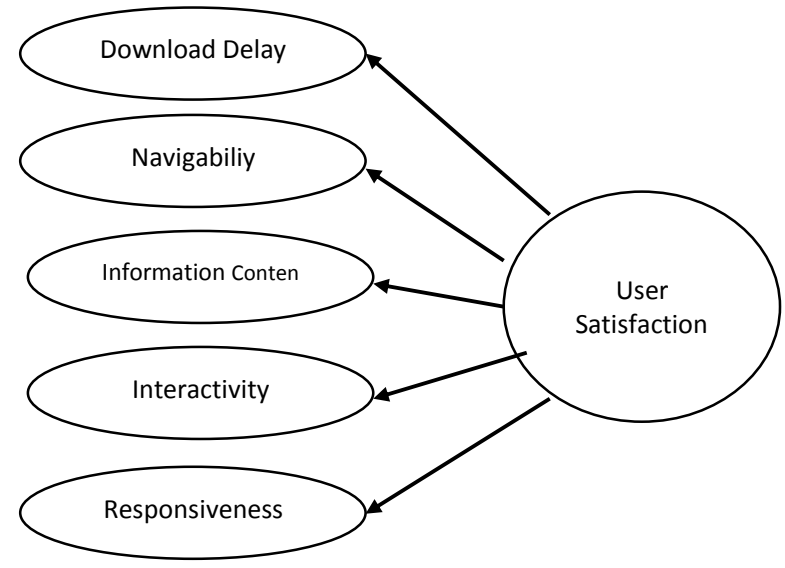

Gambar 1 Metodologi Penelitian

Tahap pertama yang penulis lakukan adalah Perancangan Model dan Pengembangan Instrumen Pengukuran :

1. Pengumpulankan data pendahuluan dilakukan melalui wawancara dan observasi dengan SPTIK dan pengguna layanan akademik di Universitas Majalengka.
2. Model dasar dalam penelitian ini adalah Customer Information Satisfaction (CIS). Model ini dipilih penulis karena yang dianggap paling sesuai dengan objek penelitian ini.

3. Model CIS yang dijadikan referensi atau dasar akan mengalami modifikasi untuk disesuaikan dengan konteks layanan SIMAK yang diteliti.

Tahan kedua Penulis melakukan adalah melakukan pengukuran dan pengembangan usulan perbaikan SIMAK :

1. Membuat sampling plan dengan mengacu pada populasi yang merupakan seluruh mahasiswa UNMA dan rencana pengolahan data dan analisis yang akan dilakukan.

2. Melakukan penyebaran kuesioner ke mahasiswa aktif tahun akademik 2014/2015 dan tahun akademik 2015/2016 dengan pertimbangan pendapat responden akan lebih valid karena pada masa tersebut mereka sedang menggunakan layanan SIMAK.

3. Pengolahan data akan mengkombinasikan statistik destriptif dengan leverage analysis untuk menentukan tingkat kepentingan dari setiap atribut layanan, dan pada akhirnya mengukur tingkat kepuasan pengguna.

4. Usulan perbaikan layanan SIMAK dilakukan berdasarkan hasil leverage analysis.

\section{HASIL DAN PEMBAHASAN}

\subsection{Hasil Penelitian}

\subsubsection{Distribusi Responden}

Berdasarkan hasil penelitian yang telah dilakukan terhadap pengguna SIMAK UNMA selama periode 2014-2015 dan 2015-2016 dengan jumlah sampel sebanyak 317 mahasiswa pada bulan September dan Oktober 2017 diperoleh hasil sebagai berikut :

Tabel 1.1

Distribusi Responden Berdasarkan Fakultas

\begin{tabular}{|c|l|c|c|}
\hline No & \multicolumn{1}{|c|}{ Fakultas } & Jumlah & Persentase \\
\hline 1 & FISIP & 31 & 9.78 \\
\hline 2 & FAPERTA & 26 & 8.2 \\
\hline 3 & FT & 41 & 12.9 \\
\hline 4 & FKIP & 64 & 20.2 \\
\hline 5 & FE & 76 & 24 \\
\hline 6 & FAI & 18 & 5.68 \\
\hline 7 & Hukum & 16 & 5.05 \\
\hline 8 & Fapendasmen & 45 & 14.2 \\
\hline & & 317 & 100 \\
\hline
\end{tabular}

Berdasarkan data diatas dapat dilihat bahwa jumlah responden tertinggi yaitu dari fakultas FE sebanyak $76(24 \%)$ dan responden terendah yaitu dari Fakultas Hukum sebanyak 16 orang $(5,05 \%)$. 
Tabel 1.2

Distribusi Responden Berdasarkan Program Studi

\begin{tabular}{|c|c|c|c|}
\hline No & Prodi & Jumlah & Persentase \\
\hline 1 & $\begin{array}{l}\text { Administrasi } \\
\text { Negara }\end{array}$ & 26 & 8.52 \\
\hline 2 & $\begin{array}{l}\text { Ilmu } \\
\text { Komunikasi }\end{array}$ & 4 & 1.26 \\
\hline 3 & Agribisnis & 9 & 3.15 \\
\hline 4 & Agroteknologi & 12 & 3.79 \\
\hline 5 & Peternakan & 4 & 0.95 \\
\hline 6 & $\begin{array}{l}\text { Teknik } \\
\text { Informatika }\end{array}$ & 24 & 7.57 \\
\hline 7 & Teknik Sipil & 6 & 1.89 \\
\hline 8 & Teknik Mesin & 9 & 2.84 \\
\hline 9 & Teknik Industri & 3 & 0.95 \\
\hline 10 & $\begin{array}{ll}\text { Pendidikan } \\
\text { Bahasa dan } \\
\text { Sastra } \\
\text { Indonesia }\end{array}$ & 6 & 1.89 \\
\hline 11 & $\begin{array}{l}\text { Pendidikan } \\
\text { Bahasa Inggris }\end{array}$ & 11 & 3.47 \\
\hline 12 & $\begin{array}{l}\text { Pendidikan } \\
\text { Jasmani } \\
\text { Kesehatan dan } \\
\text { Rekreasi } \\
\end{array}$ & 47 & 14.8 \\
\hline 13 & Akuntansi & 33 & 10.4 \\
\hline 14 & Manajemen & 43 & 13.6 \\
\hline 15 & $\begin{array}{l}\text { Hukum } \\
\text { Ekonomi } \\
\text { Syariah }\end{array}$ & 3 & 0.95 \\
\hline 16 & $\begin{array}{l}\text { Pendidikan } \\
\text { Agama Islam }\end{array}$ & 6 & 2.21 \\
\hline 17 & $\begin{array}{l}\text { Pendidikan } \\
\text { Guru } \\
\text { Roudhatul } \\
\text { Athfal } \\
\end{array}$ & 8 & 2.52 \\
\hline 18 & Ilmu Hukum & 16 & 5.05 \\
\hline 19 & $\begin{array}{l}\text { Pendidikan } \\
\text { Guru Sekolah } \\
\text { Dasar }\end{array}$ & 45 & 14.2 \\
\hline & Jumlah & 317 & 100 \\
\hline
\end{tabular}

Dari tabel 1.2 menunjukkan bahwa responden yang terpilih menjadi sampel terbanyak yaitu dari Pogram Studi Pendidikan Jasmani Kesehatan dan Rekreasi, sebanyak 47 orang $(14,8 \%)$ dan yang terendah yaitu dari hokum ekonomi syariah dan teknik industry, masing-masing berjumlah 3 orang $(0,95 \%)$.
Tabel 1.3

Distribusi Responden Berdasarkan Jenis Kelamin

\begin{tabular}{|c|c|c|c|}
\hline No & $\begin{array}{c}\text { Jenis } \\
\text { Kelamin }\end{array}$ & Jmlah & Persentase \\
\hline 1 & Laki-Laki & 1696 & 55,1 \\
\hline 2 & Perempuan & 1609 & 44,9 \\
\hline & & 3578 & 100 \\
\hline
\end{tabular}

Dsitribusi responden berdasarkan jumlah kelamin dapat dilihat pada tabel 1.3 yaitu jumlah laki-laki sebanyak 1696 orang $(55,1 \%)$ dan jumlah perempuan sebanyak 1609 orang (44,9\%). Jumlah responden laki-laki lebih banyak dibandingkan dengan perempuan.

\section{Tabel 1.4}

Distribusi Responden Berdasarkan Angkatan

\begin{tabular}{|c|c|c|c|}
\hline No & Angkatan & Jmlah & Persentase \\
\hline 1 & $2014-2015$ & 2018 & 56,4 \\
\hline 2 & $2015-2016$ & 1560 & 43,6 \\
\hline & & 3578 & 100 \\
\hline
\end{tabular}

Berdasarkan angkatan selama tahun akademik 2014-2015 jumlah responden sebanyak 2018 orang $(56,4 \%)$ dan angkatan tahun akademik 2015-2016 jumlah responden sebanyak 1560 orang $(43,6 \%)$.

\subsubsection{Pengujian Instrumen Penelitian}

Pengujian instrument penelitian (kuesioner) meliputi pengujian validitas, dan pengujian reliabilitas. Item analysis dilakukan menggunakan korelasi Pearson karena data yang berskala interval. Hasil pengujian dapat dilihat dalam tabel di bawah ini. 
Tabel 1.5

Hasil Pengujian Validitas Instrumen Penelitian

\begin{tabular}{|c|c|c|c|c|}
\hline No & Dimensi & Butir & $\begin{array}{c}\text { Factor } \\
\text { Loading }\end{array}$ & Kesimpulan \\
\hline 1 & \multirow{2}{*}{$\begin{array}{l}\text { Customer } \\
\text { service }\end{array}$} & $\begin{array}{l}\text { Portal SIMAK ini menyediakan customer } \\
\text { support sesuai dengan yang saya butuhkan }\end{array}$ & 0.957 & Valid \\
\hline 2 & & $\begin{array}{l}\text { Saya puas dengan portal SIMAK dengan } \\
\text { customer support yang disediakan. }\end{array}$ & 0.936 & Valid \\
\hline 3 & \multirow{2}{*}{ Security } & $\begin{array}{l}\text { Saya merasa aman dalam menggunakan portal } \\
\text { SIMAK ini. }\end{array}$ & 0.953 & Valid \\
\hline 4 & & $\begin{array}{l}\text { Aplikasi SIMAK ini berbasis web dan menjamin } \\
\text { keamana data pribadi saya. }\end{array}$ & 0.889 & Valid \\
\hline 5 & \multirow{3}{*}{ Innovation } & $\begin{array}{l}\text { Portal SIMAK ini cukup interaktif untuk } \\
\text { memenuhi kebutuhan saya. }\end{array}$ & 0.742 & Valid \\
\hline 6 & & $\begin{array}{l}\text { Menurut saya Portal SIMAK ini cukup fleksibel. } \\
\text { (Bisa diakses dari mana saja, kapan saja, } \\
\text { menggunakan browser apa saja) }\end{array}$ & 0.943 & Valid \\
\hline 7 & & $\begin{array}{l}\text { Menurut saya Portal SIMAK ini beroperasi } \\
\text { dengan stabil. }\end{array}$ & 0.954 & Valid \\
\hline 8 & \multirow{4}{*}{ Content } & $\begin{array}{l}\text { Portal SIMAK ini menyediakan informasi yang } \\
\text { lengkap dan komprehensif. }\end{array}$ & 0.940 & Valid \\
\hline 9 & & $\begin{array}{l}\text { Portal SIMAK ini menyediakan informasi yang } \\
\text { Biasa saya percaya. }\end{array}$ & 0.947 & Valid \\
\hline 10 & & $\begin{array}{l}\text { Portal SIMAK ini menyediakan informasi yang } \\
\text { up to date. }\end{array}$ & 0.931 & Valid \\
\hline 11 & & $\begin{array}{l}\text { Portal SIMAK ini menyediakan informasi yang } \\
\text { akurat. }\end{array}$ & 0.975 & Valid \\
\hline 12 & \multirow{3}{*}{ Ease of use } & $\begin{array}{llll}\begin{array}{l}\text { Kecepatan } \\
\text { dibutuhkan }\end{array} & \text { mendapatkan } & \text { informasi } & \text { yang } \\
\end{array}$ & 0.653 & Valid \\
\hline 13 & & User friendliness & 0.973 & Valid \\
\hline 14 & & Kemudahan menggunakan Portal SIMAK & 0.895 & Valid \\
\hline 15 & \multicolumn{2}{|c|}{$\begin{array}{l}\text { Secara Keseluruhan bagaimana kepuasan anda terhadap } \\
\text { layanan SIMAK }\end{array}$} & 0.895 & Valid \\
\hline
\end{tabular}

Hasil uji validitas pada tabel 1.5 menunjukkan bahwa dari 15 butir pertanyaan semuanya valid karena nilai faktor loading $>0,60$. Sehingga dapat disimpulkan bahwa semua item pertanyaan valid.

Tabel 1.6

Hasil Pengujian Reliabilitas Instrumen Penelitian

\begin{tabular}{|c|l|c|c|}
\hline No & \multicolumn{1}{|c|}{ Dimensi } & $\begin{array}{c}\text { Nilai } \\
\text { Cronbach } \\
\text { Alpha }\end{array}$ & Kesimpulan \\
\hline 1 & $\begin{array}{l}\text { Customer } \\
\text { service }\end{array}$ & 0,958 & Reliabel \\
\hline 2 & Security & 0,935 & Reliabel \\
\hline 3 & Innovation & 0,907 & Reliabel \\
\hline 4 & Content & 0,976 & Reliabel \\
\hline 5 & Ease of use & 0,870 & Reliabel \\
\hline
\end{tabular}

Pengujian reliabilitas instrument dilakukan menggunakan Alpha Cronbach, dan hasilnya dapat dilihat pada Tabel 1.6 Berdasarkan nilai Alpha Cronbach dapat disimpulkan bahwa semua dimensi reliabel, sehingga instrument penelitian reliabel. Dengan demikian dapat disimpulkan bahwa instrument penelitian bisa digunakan dalam pengukuran 


\subsubsection{Kepuasan Pengguna Layanan Akademik Online Secara Keseluruhan}

Tabel 1.7

Kepuasan Pengguna SIMAK

\begin{tabular}{|c|c|}
\hline $\begin{array}{l}\text { Menyediakan customer support sesuai } \\
\text { kebutuhkan }\end{array}$ & 4.18 \\
\hline $\begin{array}{l}\text { Saya puas dengan portal SIMAK } \\
\text { dengan customer } \\
\text { disediakan. }\end{array}$ & 3.67 \\
\hline $\begin{array}{l}\text { Aman dalam menggunakan portal } \\
\text { SIMAK }\end{array}$ & 4.13 \\
\hline $\begin{array}{l}\text { Aplikasi SIMAK berbasis } \text { web } \\
\text { menjamin keamana data pribadi }\end{array}$ & 4.18 \\
\hline $\begin{array}{l}\text { Portal SIMAK cukup interaktif untuk } \\
\text { memenuhi kebutuhan }\end{array}$ & 4.02 \\
\hline $\begin{array}{l}\text { Portal SIMAK cukup fleksibel. (Bisa } \\
\text { diakses dari mana saja, kapan saja, } \\
\text { menggunakan browser apa saja) }\end{array}$ & 4.14 \\
\hline $\begin{array}{l}\text { Portal SIMAK ini beroperasi dengan } \\
\text { stabil. }\end{array}$ & 3.39 \\
\hline $\begin{array}{l}\text { Portal SIMAK menyediakan informasi } \\
\text { lengkap dan komprehensif }\end{array}$ & 4.16 \\
\hline $\begin{array}{l}\text { Portal SIMAK menyediakan informasi } \\
\text { yang Biasa dipercaya. }\end{array}$ & 4.04 \\
\hline $\begin{array}{l}\text { Portal SIMAK menyediakan informasi } \\
\text { yang up to date. }\end{array}$ & 4.13 \\
\hline $\begin{array}{l}\text { Portal SIMAK menyediakan informasi } \\
\text { yang akurat. }\end{array}$ & 4.17 \\
\hline $\begin{array}{l}\text { Kecepatan mendapatkan informasi } \\
\text { yang dibutuhkan }\end{array}$ & 4.1 \\
\hline User friendliness & 4.16 \\
\hline $\begin{array}{l}\text { Kemudahan dalam menggunakan } \\
\text { Portal SIMAK }\end{array}$ & 4.02 \\
\hline
\end{tabular}

Secara keseluruhan, tingkat kepuasan mahasiswa terhadap layanan akademik online UNMA adalah sebesar 3,98 pada skala 4, atau sebesar $79,6 \%$. Dari semua atribut pernyataan "portal SIMAK ini beroperasi dengan stabil" memperoleh persepsi paling rendah $(3,39)$. Adapun atribut customer support dan SIMAK berbasis web menjamin keamana data pribadi memperoleh persepsi paling tinggi $(4,18)$ menunjukkan bahwa terkait pelayanan dan keamanan data pribadi mahasiswa telah terpenuhi.

\subsubsection{Kepuasan Pengguna Layanan Akademik Online Berdasarkan Fakultas}

Dalam bagian ini akan dipaparkan kepuasan pengguna layanan akademik online (SIMAK) berdasarkan fakultas. Tingkat kepuasan pengguna layanan akademik online rata-rata untuk setiap fakultas dapat dilihat dalam diagram 2 di bawah ini:

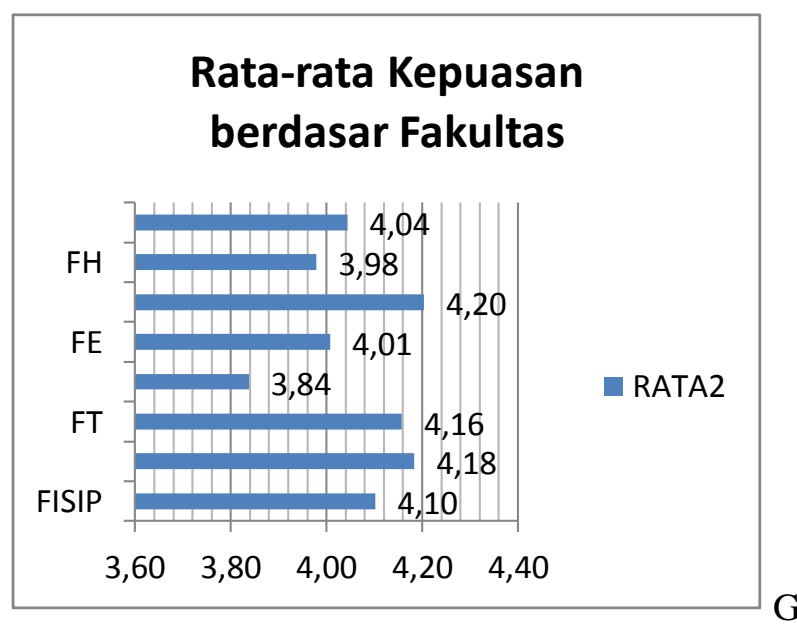

ambar 2

Rata-rata tingkat kepuasan pengguna SIMAK

Berdasarkan data diatas kepuasan mahasiswa berdasarkan fakultas diperoleh hasil bahwa fakultas dengan rata-rata kepuasan terendah yaitu FKIP sebesar 3,84 dan kepuasan mahasiswa tertinggi adalah FAI dengan rata-rata sebesar 4,20. Kepuasan Pengguna Layanan Akademik Online Berdasarkan Atribut

Selanjutnya akan penulis paparkan kualitas layanan akademik SIMAK per atribut berdasarkan fakultas.

\section{Kualitas Layanan SIMAK untuk Mahasiswa FISIP}

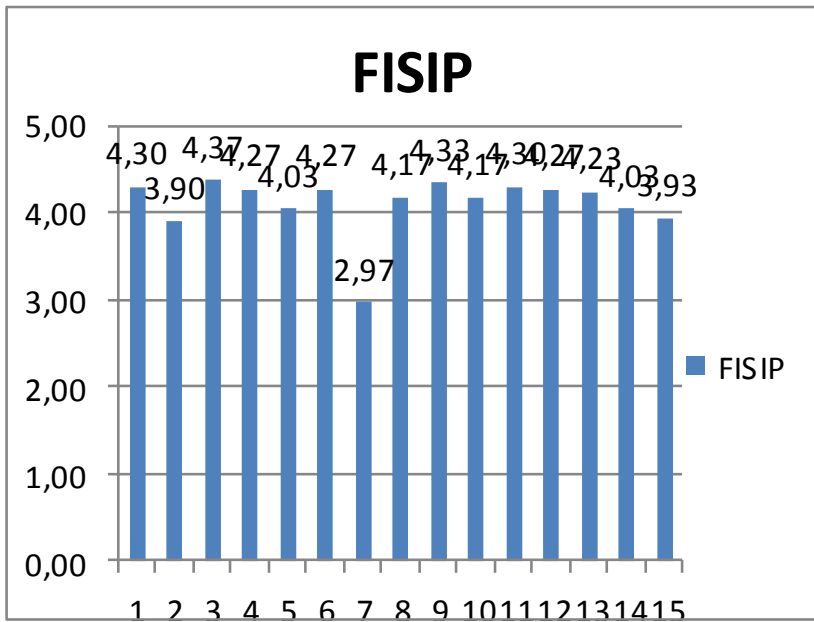

Gambar 3

Kualitas layanan berdasarkan atribut untuk mahasiswa FISIP

Dari diagram diatas dapat dilihat bahwa tingkat kepuasan mahasiswa pada fakultas FISIP dengan rata-rata terendah sebesar 2,97 yaitu pada pernyataan tentang Portal SIMAK ini beroperasi dengan stabil, sedangkan rata-rata tertinggi tingkat kepuasan 
sebesar 4,37 yaitu pada pernyataan tentang "merasa aman dalam menggunakan portal SIMAK ini"

2. Kualitas Layanan SIMAK untuk Mahasiswa FAPERTA

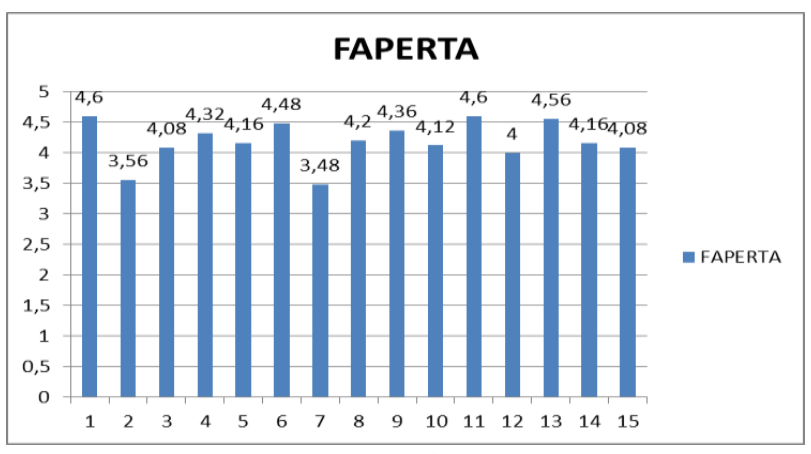

Gambar 4

Kualitas layanan berdasarkan atribut untuk mahasiswa FAPERTA

Berdasarkan diagram diatas dapat dilihat bahwa tingkat kepuasan mahasiswa pada fakultas FAPERTA dengan rata-rata terendah sebesar 3,48 yaitu pada pernyataan tentang "Portal SIMAK ini beroperasi dengan stabil", sedangkan rata-rata tertinggi tingkat kepuasan sebesar 4,6 yaitu pada pernyataan tentang "Portal SIMAK ini menyediakan customer support sesuai dengan yang saya butuhkan"

\section{Kualitas Layanan SIMAK untuk Mahasiswa Fakultas Teknik}

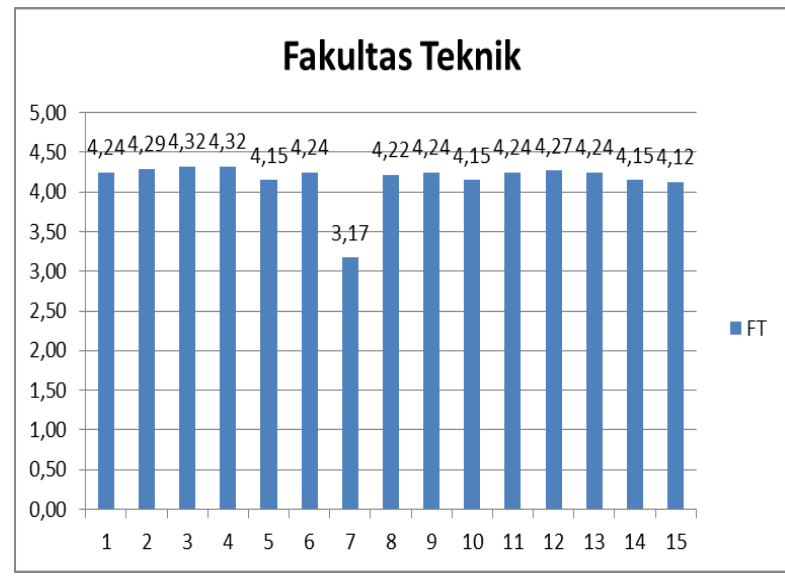

Gambar 5

Kualitas layanan berdasarkan atribut untuk mahasiswa FT

Berdasarkan diagram diatas dapat dilihat bahwa tingkat kepuasan mahasiswa pada Fakultas Teknik dengan rata-rata terendah sebesar 3,17 yaitu pada pernyataan tentang "Portal SIMAK ini beroperasi dengan stabil", sedangkan rata-rata tertinggi tingkat kepuasan sebesar 4,32 yaitu pada pernyataan tentang "merasa aman dalam menggunakan portal SIMAK ini".

\section{Kualitas Layanan SIMAK untuk Mahasiswa FKIP}

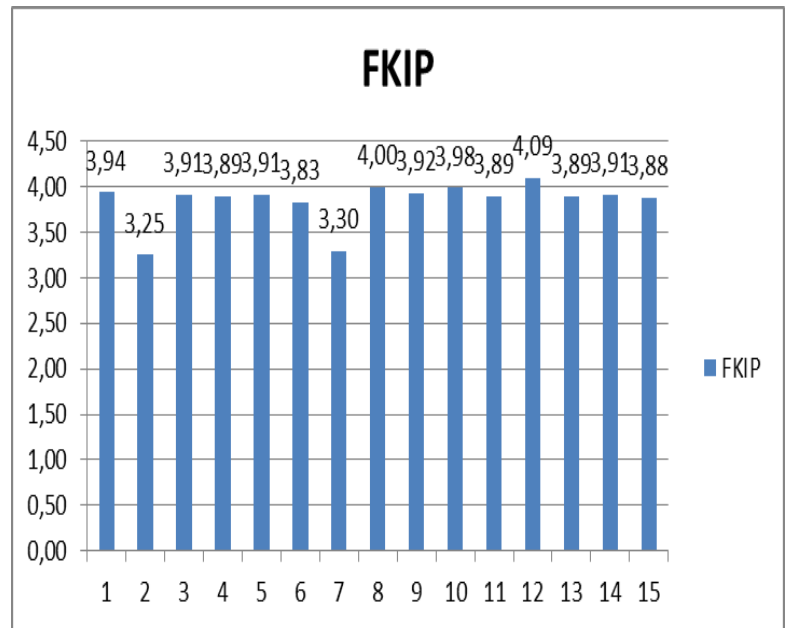

Gambar 6

Kualitas layanan berdasarkan atribut untuk mahasiswa FKIP

Berdasarkan diagram 6 dapat dilihat bahwa tingkat kepuasan mahasiswa pada Fakultas FKIP dengan rata-rata terendah sebesar 3,25 yaitu pada pernyataan tentang "Saya puas dengan customer support yang disediakan", sedangkan rata-rata tertinggi tingkat kepuasan sebesar 4,09 yaitu pada pernyataan tentang "Kecepatan mendapatkan informasi yang dibutuhkan".

\section{Kualitas Layanan SIMAK untuk Mahasiswa} FE

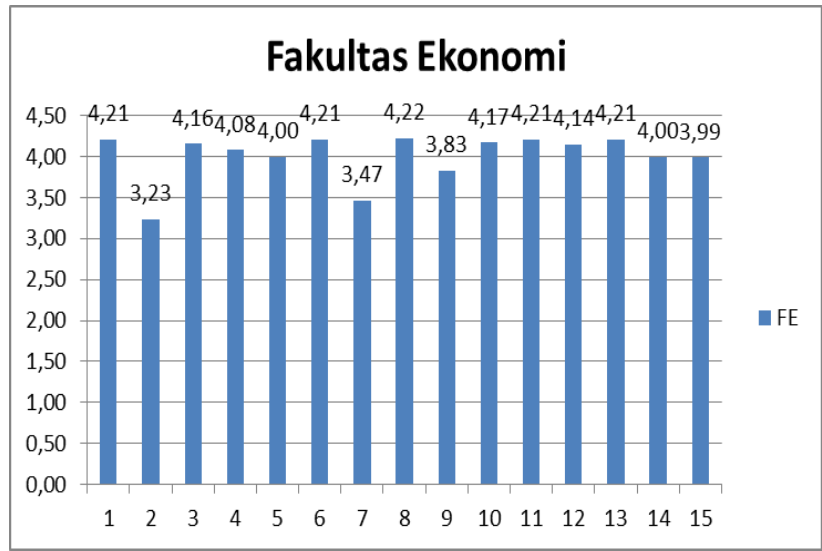

Gambar 7

Kualitas layanan berdasarkan atribut untuk mahasiswa FE 
Berdasarkan diagram 7 dapat dilihat bahwa tingkat kepuasan mahasiswa pada Fakultas Ekonomi dengan rata-rata terendah sebesar 3,23 yaitu pada pernyataan tentang "Saya puas dengan customer support yang disediakan", sedangkan rata-rata tertinggi tingkat kepuasan sebesar 4,22 yaitu pada pernyataan tentang "Portal SIMAK ini menyediakan informasi yang lengkap dan komprehensif".

\section{Kualitas Layanan SIMAK untuk Mahasiswa FAI}

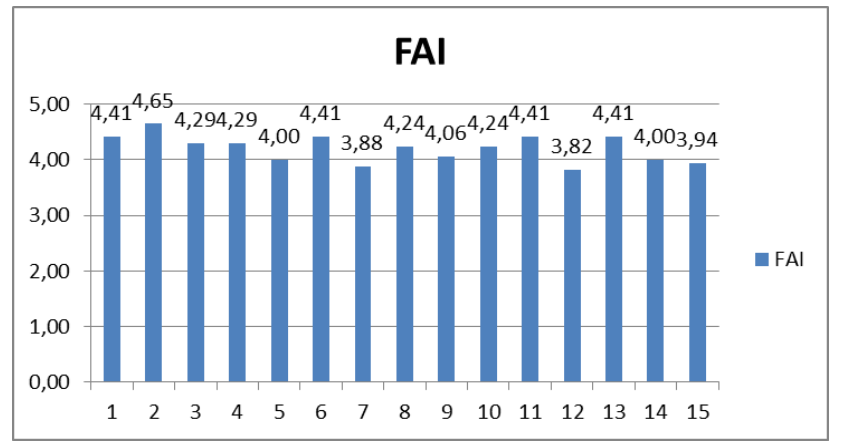

Gambar 8

Kualitas layanan berdasarkan atribut untuk mahasiswa FAI

Berdasarkan diagram 8 dapat dilihat bahwa tingkat kepuasan mahasiswa pada Fakultas Agama Islam dengan rata-rata terendah sebesar 3,82 yaitu pada pernyataan tentang "Kecepatan mendapatkan informasi yang dibutuhkan", sedangkan rata-rata tertinggi tingkat kepuasan sebesar 4,65 yaitu pada pernyataan tentang "Saya puas dengan customer support yang disediakan".

7. Kualitas Layanan SIMAK untuk Mahasiswa Fakultas Hukum

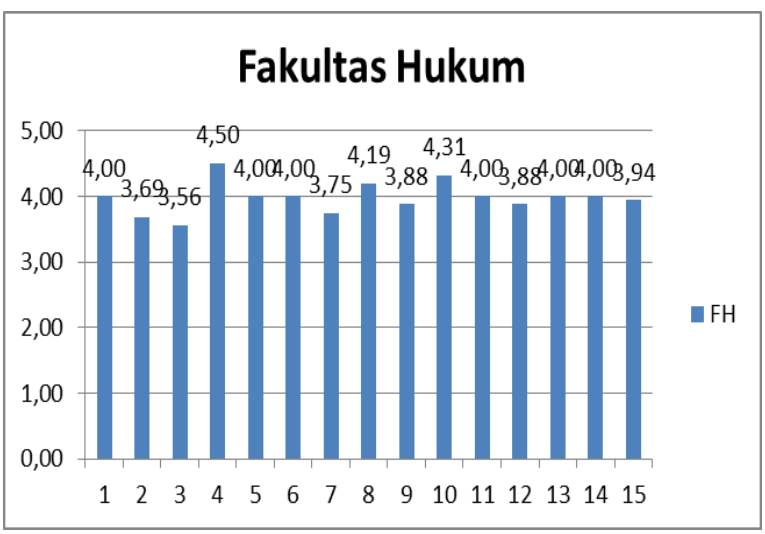

Gambar 9

Kualitas layanan berdasarkan atribut untuk mahasiswa FH

Berdasarkan diagram 9 dapat dilihat bahwa tingkat kepuasan mahasiswa pada Fakultas Hukum dengan rata-rata terendah sebesar 3,56 yaitu pada pernyataan tentang "Saya merasa aman dalam menggunakan portal SIMAK ini", sedangkan rata-rata tertinggi tingkat kepuasan sebesar 4,50 yaitu pada pernyataan tentang "Aplikasi SIMAK ini berbasis web dan menjamin keamana data pribadi saya".

\section{Kualitas Layanan SIMAK untuk Mahasiswa PGSD}

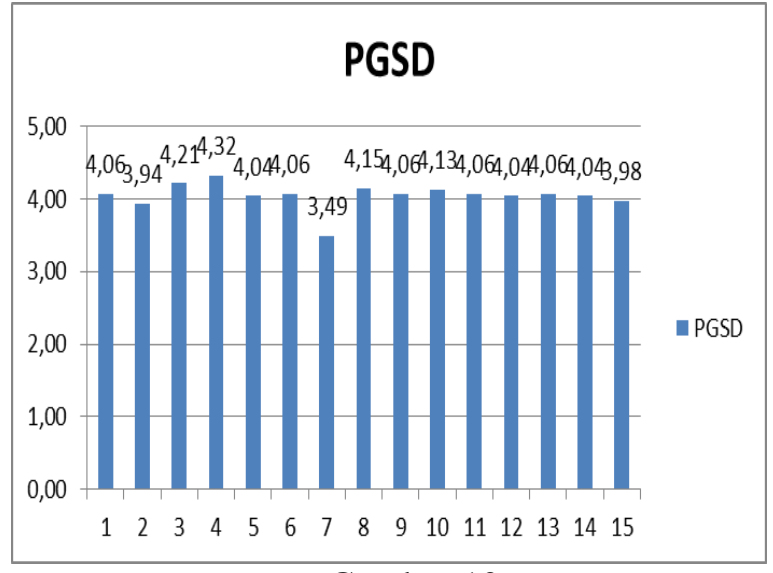

Gambar 10

Kualitas layanan berdasarkan atribut untuk mahasiswa PGSD

Berdasarkan diagram 10 dapat dilihat bahwa tingkat kepuasan mahasiswa pada Fakultas PGSD dengan rata-rata terendah sebesar 3,49 yaitu pada pernyataan tentang "Menurut saya Portal SIMAK ini beroperasi dengan stabil", sedangkan rata-rata tertinggi tingkat kepuasan sebesar 4,32 yaitu pada pernyataan tentang "Aplikasi SIMAK ini berbasis web dan menjamin keamana data pribadi saya".

\subsubsection{Importance Performance Analysis (IPA)}

IPA merupakan suatu metode analisis yang merupakan kombinasi antara aspek-aspek tingkat kepentingan dan persepsi terhadap kepuasan pengguna. Ada dua parameter dalam analisis ini, yaitu yang diwakili oleh persepsi dan harapan, hasil analisis IPA dapat dilihat pada diagram di bawah ini 


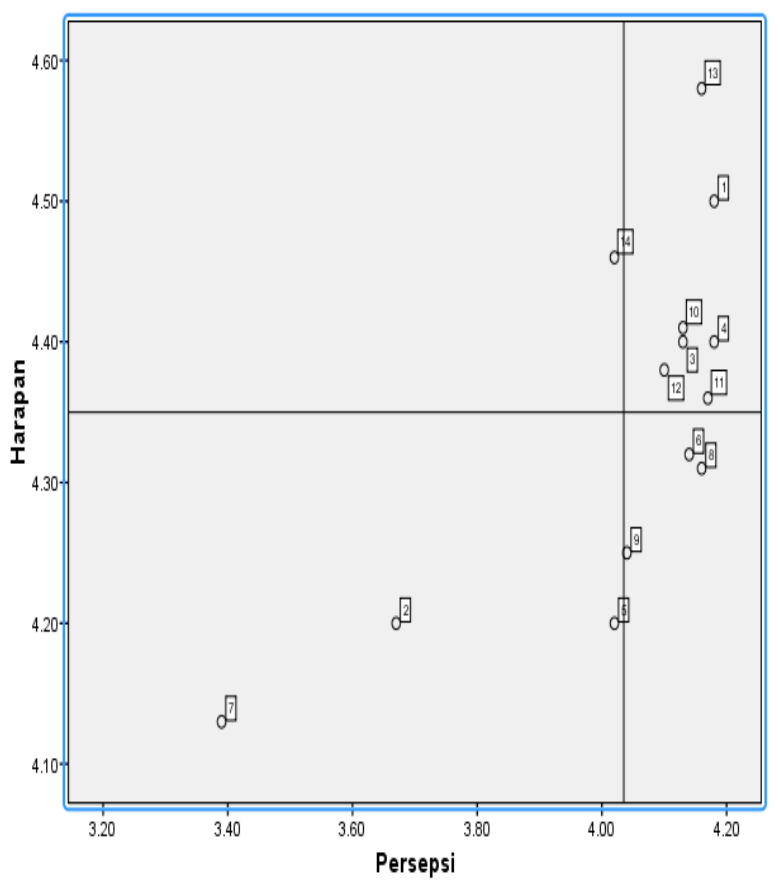

Kuadran Importance Performance Analysis (IPA) untuk kepuasan pengguna layanan akademik online SIMAK UNMA adalah sebagai berikut :

\begin{tabular}{|c|c|}
\hline \begin{tabular}{l}
\multicolumn{2}{c}{ Kuadran I } \\
Prioritas Utama \\
(Concentrate Here) \\
Atribut pada kuadran \\
ini dianggap sangat \\
penting oleh pengguna \\
tetapi pelayanannya \\
tidak memuaskan \\
sehingga rarus \\
meningkatkan kualitas \\
pelayanannya.
\end{tabular} & \begin{tabular}{l}
\multicolumn{2}{c}{ Kuadran II } \\
Pertahankan Prestasi \\
(Keep Up The Good \\
Work) \\
Atribut pada kuadran \\
ini dianggap sangat \\
penting oleh \\
pengguna dan \\
pelayanannya sangat \\
memuaskan, \\
sehingga harus \\
mempertahankan \\
kualitas \\
pelayanannya
\end{tabular} \\
\hline $\begin{array}{l}\text { Kuadran III } \\
\text { Prioritas Rendah } \\
\text { (Low Priority) } \\
\text { Atribut pada kuadran } \\
\text { ini dianggap tidak } \\
\text { penting oleh pengguna } \\
\text { dan pelayanannya } \\
\text { kurang memuaskan. }\end{array}$ & \begin{tabular}{l}
\multicolumn{2}{c}{ Kuadran IV } \\
Berlebihan \\
(Possible Overkill) \\
Atribut pada kuadran \\
ini dianggap tidak \\
penting \\
pengguna oleh \\
pelayanannya \\
memuaskan.
\end{tabular} \\
\hline
\end{tabular}

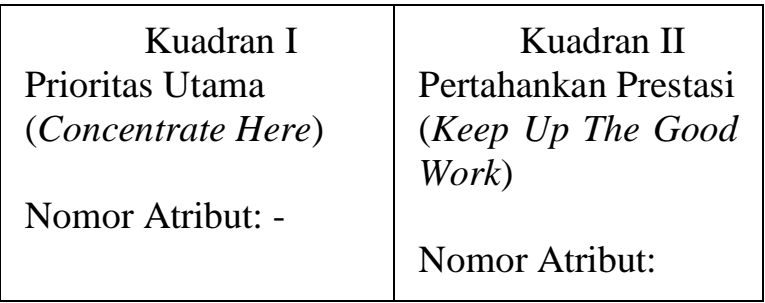

\begin{tabular}{|c|c|}
\hline & $\begin{array}{l}1,3,4,10,11,12, \\
13,14\end{array}$ \\
\hline $\begin{array}{l}\quad \text { Kuadran III } \\
\text { Prioritas Rendah } \\
\text { (Low Priority) }\end{array}$ & $\begin{array}{l}\quad \text { Kuadran IV } \\
\text { Berlebihan } \\
\text { (Possible Overkill) }\end{array}$ \\
\hline $\begin{array}{l}\text { Nomor Atribut: } \\
7,2\end{array}$ & $\begin{array}{l}\text { Nomor Atribut: } \\
5,6,8,9\end{array}$ \\
\hline
\end{tabular}

Pengambilan Keputusan (IPA) adalah sebagai berikut :

1. Kuadran I (Prioritas Utama)

Atribut-atribut yang berada pada kuadran ini dianggap sangat penting oleh penggunan layanan akademik online tetapi pelayanannya tidak memuaskan. Atribut-atribut ini prioritas utama untuk segera dilakukan perbaikan oleh Universitas.

Hasil analisis IPA tidak ada atribut kepuasan pengguna layanan akademik online SIMAK UNMA yang masuk pada kuadran I

Unversitas memprioritaskan untuk fokus memperbaiki atribut-atribut yang berada pada kuadran III.

2. Kuadran II (Pertahankan Prestasi)

Atribut-atribut yang berada pada kuadran ini dianggap sangat penting oleh pengguna layanan akademik online dan pelayanannya sangat memuaskan.

Atribut 1 : Menyediakan customer support sesuai kebutuhkan

Atribut 3 : Aman dalam menggunakan portal SIMAK

Atribut $4 \quad$ : Aplikasi SIMAK berbasis web menjamin keamana data pribadi

Atribut 10 : Portal SIMAK menyediakan informasi yang up to date

Atribut 11 : Portal SIMAK menyediakan informasi yang akurat

Atribut 12 : Kecepatan mendapatkan informasi yang dibutuhkan

Atribut 13 : User friendliness

Atribut 14 : Kemudahan dalam menggunakan Portal SIMAK

Kesimpulan:

Pengguna sangat puas. Unversitas harus mempertahankan atribut-atribut kepuasan pengguna yang berada pada kuadran ini. 
3. Kuadran III (Prioritas Rendah)

Atribut-atribut pada kuadran ini dianggap tidak terlalu penting oleh pengguna layanan akademik online dan pelayanannya kurang memuaskan.

Hasil Analisis:

Atribut 2 : Saya puas dengan portal SIMAK dengan customer support yang disediakan

Atribut 7 : Portal SIMAK ini beroperasi dengan stabil

Kesimpulan:

Unversitas memprioritaskan untuk fokus memperbaiki atribut-atribut yang berada pada kuadran ini, dikarenakan pelayanannya tidak memuaskan.

4. Kuadran IV (Berlebihan)

Atribut-atribut yang berada pada kuadran ini dianggap tidak terlalu penting oleh pengguna tetapi pelayanannya memuaskan

Atribut 5 : Portal SIMAK cukup interaktif untuk memenuhi kebutuhan

Atribut 6 : Portal SIMAK cukup fleksibel. (Bisa diakses dari mana saja, kapan saja, menggunakan browser apa saja)

Atribut 8 : Portal SIMAK menyediakan informasi lengkap dan komprehensif

Atribut 9 : Portal SIMAK menyediakan

Kesimpulan : informasi yang Bisa dipercaya

Pengguna layanan akademik online sudah merasakan puas atas pelayanan yang diberikan oleh pengelola layanan SIMAK.

\subsection{Pembahasan}

\subsubsection{Analisis Pengujian Instrumen}

Instrument pengukuran yang digunakan dalam penelitian ini dibangun berdasarkan model yang sudah terbukti valid, yaitu Customer Information Satisfaction (CIS). Pengujian instrument penelitian dilakukan meliputi pengujian validitas, dan pengujian reliabilitas, instrument terbukti valid dan reliable. Hasil Pengujian validitas dengan analisis faktor konfirmatori juga menghasilkan factor loading yang seluruhnya di atas 0,50 yang merupakan batas minimal signifikan. Semua dimensi pengukuran juga terbukti reliable dengan nilai Alpha Cronbach berkisar 0,870-0,976, di atas batas 0,70.

\subsubsection{Analisis Sampling dan Pelaksanaan Survey}

Teknik sampling yang digunakan dalam penelitian ini menggunakan propotional simple random sampling, yaitu sampel yang diambil secara propotional dari setiap program studi yang ada di Universitas Majalengka, teknik ini dipilih agar setiap populasi yang tersebar di setiap program studi memiliki kesempatan yang sama untuk menjadi responden penelitian. Adapun pelaksanaan survey dalam penelitian ini dilakukan di setiap program study mahasiswa yang di pilih adalah angkatan tahun 2014/2015 yang di pilih secara acak sesuai dengan jumlah sampel yang sudah ditentukan jumlahnya di setiap Program Studi Universitas Majalengka.

\subsubsection{Analisis Hasil Pengolahan Data}

\subsubsection{AnalisisTingkat Kepuasan Keseluruhan}

Secara keseluruhan, tingkat kepuasan mahasiswa terhadap layanan akademik online UNMA adalah sebesar 3,98 pada skala 4, atau sebesar $79,6 \%$. Dari semua atribut pernyataan "portal SIMAK ini beroperasi dengan stabil" memperoleh persepsi paling rendah $(3,39)$. Adapun atribut customer support dan SIMAK berbasis web menjamin keamana data pribadi memperoleh persepsi paling tinggi $(4,18)$ menunjukkan bahwa terkait pelayanan dan keamanan data pribadi mahasiswa telah terpenuhi.

\subsubsection{AnalisisTingkat Kepuasan per Fakultas}

Pengukuran kepuasan mahasiswa terhadap layanan akademik SIMAK UNMA berdasarkan Fakultas diperoleh hasil bahwa fakultas dengan ratarata kepuasan terendah yaitu FKIP sebesar 3,84 dan kepuasan mahasiswa tertinggi adalah FAI dengan rata-rata sebesar 4,20.

\subsubsection{Kepuasan Pengguna Layanan}

\section{Akademik Online Berdasarkan Atribut}

Kepuasan mahasiswa terhadap layanan akademik atau SIMAK UNMA berdasarkan atribut pada fakultas FAPERTA, FT, PGSD yang dinilai kurang baik adalah pernyataan tentang "Portal SIMAK ini beroperasi dengan stabil". Untuk fakultas FKIP dan FE yang dinilai kurang baik adalah pada pernyataan "Saya puas dengan customer support yang disediakan". Untuk Fakultas Agama Islam yang dinilai kurang baik adalah pada pernyataan tentang "Kecepatan mendapatkan informasi yang dibutuhkan". Sedangkan untuk Fakultas Hukum yang dinilai kurang baik adalah pada pernyataan "Saya merasa aman dalam menggunakan portal SIMAK ini".Menurut FAPERTA Atribut yang dinilai memiliki kinerja paling baik adalah pada pernyataan tentang "Portal SIMAK ini menyediakan customer support sesuai dengan yang saya butuhkan". Untuk Fakultas Teknik Atribut yang dinilai memiliki kinerja paling baik adalah pada pernyataan tentang "merasa aman dalam 
menggunakan portal SIMAK ini".Untuk Fakultas FKIP Atribut yang dinilai memiliki kinerja paling baik adalah pada pernyataan tentang "Kecepatan mendapatkan informasi yang dibutuhkan". Untuk Fakultas Ekonomi Atribut yang dinilai memiliki kinerja paling baik adalah pada pernyataan tentang "Portal SIMAK ini menyediakan informasi yang lengkap dan komprehensif". Untuk Fakultas Agama Islam Atribut yang dinilai memiliki kinerja paling baik adalah pada pernyataan tentang "Saya puas dengan customer support yang disediakan". Sedangkan untuk Fakultas Hukum dan PGSD Atribut yang dinilai memiliki kinerja paling baik adalah pada pernyataan tentang "Aplikasi SIMAK ini berbasis web dan menjamin keamana data pribadi saya".

\subsubsection{Analisis Hasil Importance Performance Analysis (IPA)}

Importance Performance Analysis (IPA) bertujuan menentukan fokus upaya perbaikan terhadap sistem yang ada saat ini. Fokus perbaikan ada pada atribut-atribut yang terletak di kuadran III, yaitu kelompok atribut yang dianggap tidak terlalu penting oleh pengguna layanan akademik online dan pelayanannya kurang memuaskan. Ini adalah kelompok atribut yang jika diperbaiki akan berdampak relative besar pada peningkatan kepuasan pengguna.

Atribut yang menjadi fokus perbaikan adalah: Atribut 2 : Saya puas dengan portal SIMAK dengan customer support yang disediakan dan Atribut 7 : Portal SIMAK ini beroperasi dengan stabil. Pengelola layanan akademik SIMAK UNMA agar memprioritaskan untuk fokus memperbaiki atribut-atribut yang berada pada kuadran ini, dikarenakan pelayanannya tidak memuaskan.

\subsection{Peningkatan Layanan SIMAK \\ 3.3.1 Usulan Inisiatif Perbaikan}

Berdasarkan hasil Analisis Importance Performance Analysis (IPA) diatas maka yang menjadi usulan perbaikan pada Sistem Imformasi Akademik di Universitas Majalengka adalah pertama, pengguna SIMAK ada yang merasa kesulitan untuk berinteraksi ketika menghadapi kendala atau kesulitan dalam menggunakan SIMAK sehingga diperlukan layanan akademik online, maka penulis menyarankan penambahan fasilitas menu support atau Customer service (Hotline) untuk memudahkan pengguna dalam berinteraksi dengan bagian akademik secara real time. Usulan perbaikan yang kedua, adalah

\section{KESIMPULAN}

\subsection{Kesimpulan}

Secara keseluruhan, tingkat kepuasan mahasiswa terhadap layanan akademik online atau SIMAK UNMA adalah sebesar 3,98 pada skala 4, atau sebesar 79,6\%, sehingga Pengguna layanan akademik online atau SIMAK UNMA ini sudah merasakan puas atas pelayanan yang diberikan oleh pengelola layanan SIMAK memperoleh persepsi paling rendah sebesar 3,39.

Adapun atribut customer support dan SIMAK berbasis web menjamin keamana data pribadi memperoleh persepsi paling tinggi $(4,18)$ menunjukkan bahwa terkait pelayanan dan keamanan data pribadi mahasiswa telah terpenuhi.

\subsection{Saran}

1. Pengukuran Kepuasan Pengguna SIMAK sebaiknya dilakukan secara periodik dengan frekuensi minimal setahun 2 kali atau satu semester sekali.

2. Hasil pengukuran melalui Kuesioner sebaiknya diperkuat dengan data hasil wawancara dengan sejumlah pengguna dan SPTIK, yang bertujuan untuk memperkuat analisis IPA yang mengarah ke identifikasi inisiatif perbaikan terhadap SIMAK.

\section{REFERENSI}

Agarwal, R., \& Venkatesh, V. (2002). Assessing a firm's Web presence: a heuristicmeasurement of usability. Information System Research, 13, 168-186.

Cooper, Donald dan Pamela Schindler. (2013). Business Research Methods. $12^{\text {th }}$ Edition. New York : McGraw-Hill Higher Education.

Gupta M.P, Kanungo S, Kumar R and Sahu G.P,2007. "A Study of Information Technology Efectiveness in Select Government Organizationsin India". Journal for Decision Makers. Vol 32. No.2.

Mardiana, Ardi. Tingkat Kepuasan Mahasiswa Terhadap Kinerja Sistem Informasi Akademik dan Keuangan (Studi Kasus: Universitas Majalengka). Infotech Journal, 2016, 1.2.

Turban \& Gehrke Dave. 2000. "Determinants of E-Commerce Website". Human System Management, Vol. 19, No. 2. pp. 111120.Hlm: 1

Yaghoubi, N. M. et al., 2011. Internet bookstore quality assessment: Iranian evidence. African Journal of Business Management, V(30), pp. 12031-12039. 